\title{
ANALYSIS OF ACTIVITIES AIMED AT INCREASING THE VALUE OF PROPERTY - RESEARCH RESULTS
}

\author{
Katarzyna Kocur-Bera, PhD \\ Faculty of Geodesy and Land Management \\ University of Warmia and Mazury in Olsztyn \\ e-mail:katarzyna.kocur@uwm.edu.pl
}

\section{Małgorzata Dudzińska, PhD}

Faculty of Geodesy and Land Management

University of Warmia and Mazury in Olsztyn

e-mail:gosiadudzi@uwm.edu.pl

\begin{abstract}
The main aim of the study was to analyse the possibilities of increasing the market value of a property through various activities. Such activities referred to in the literature as "value based management" and are commonly applied in enterprise management. In the case of properties, this system is based on the appropriate identification of factors making up the value of the property. These factors can be divided into two groups, i.e., objective factors, independent of activities undertaken by the owner or the manager of the property, and subjective factors resulting from a consciously implemented policy. Since only the second group of activities depends on the property manager, it is possible to introduce "value based management" with regard to the manager's activities. This article presents a case study implemented on a part of hospital property. The analysis proved that the method used can also be applied to undeveloped parts of the property and that the market value of the property in individual investigated scenarios reaches $100 \%$.
\end{abstract}

Keywords: value based management on property, activities aimed at increasing the value of property.

JEL Classification: R 19.

Citation: Kocur-Bera K., Dudzińska M., (2013), “Analysis of activities to increase the value of property - research results", Real Estate Management and Valuation, vol. 21, no. 2, pp. 64-71.

DOI: $10.2478 /$ remav-2013-0018.

\section{Introduction}

In developed market economies, properties play an increasingly important role among factors promoting efficiency. Properties make up a part of their owners' assets. The reasonable management of properties, regardless of their type, function, condition and manner of use, aims at maximising their value. The tasks of managers include the adjustment of the property portfolio and implementation of management strategies to increase the value of the properties owned (RYMRZAK 2010). Because of the diversity of properties and certain technical, economic, organisational and social barriers, there is no universal method for modelling the value of property.

The aim of this article is to identify activities affecting an increase in the market value of a property. The first part focuses on explaining the issues related to value based property management, while the second presents a case study aimed at indicating activities leading to an increase in the market value of a given property in order to increase the budget of the local government unit (in this case, the district government). The aim was achieved through the analysis of literature and the case study method. 
The study was based on activities that could be conducted on the hospital property located in Brodnica, in the Kujawsko-Pomorskie Voivodeship. All of the presented scenarios are feasible and the property owner (in this case, a local government unit) is currently implementing the most advantageous scenario.

\section{The concept of value-based management}

The concept of value-based management (VBM) can be traced back to the field of enterprise management. Such management is a management system containing tools and procedures for taking strategic and operating decisions to achieve a long-term value increase and multiplication of the owner's assets (SZABLEWSKI 2011). VBM is, therefore, a value-oriented system of management. The idea is that the value of the property is the basic purpose behind the existence of this system. Since it shows the need to maximise the value for all stakeholders, it is considered universal (WAŚNIEWSKI 2011). The concept of VBM is based on three elements: value creation, measurement and management (Copeland et al., 1990).

Within the property, its value is determined by various factors. Therefore, an increase in property value, or at least ensuring its stability at the present level, in each case requires an individual management method.

One of the most important elements contributing to the genesis of value-based management (VBM) is the separation of property ownership from its management, which means that the owners do not directly fulfil their managerial functions but delegate them to certain persons or entities hired for this purpose.

The application of the VBM concept in the field of property management consists of constructing a systemic, coherent and complex process of identifying and creating values of properties in individual management areas in order to reach the highest possible level. This requires the identification and understanding of factors affecting the level of property value, since only then is it possible to create a permanent mechanism ensuring its permanent growth.

The multifaceted care of a given property contributes to the improvement of its general situation, ensures a long-term favourable market position of the facility and, consequently, results in an increase in property value.

In the VBM approach, it is crucial to properly recognise factors making up the value of the property. These factors can be divided into two groups, i.e., objective factors, independent of activities undertaken by the owner or the manager of the property, and subjective factors, resulting from a consciously implemented policy (UHRUSKA 2008).

Within the field of property management, the implementation of "value-based management" can be divided into the following stages:

- assessment of the property (e.g., physical and environmental factors, development possibilities, etc.);

- analysis of components making up the property management system (e.g., elements which should be taken into account in this system);

- indication of key measures for effective management;

- development of a property value simulation model;

- establishment of aims related to the increase of the property value;

- development of a strategy (scenarios) of increasing property value;

- development of a form of supervising the implementation of the value-based management system.

The implementation of the value increase strategy requires detailed planning and budgeting. Due to financial constraints, these aims often cannot be pursued at the same time. Therefore, action plans containing an analysis of costs and benefits of a given undertaking should be developed, the most necessary actions selected and other aims arranged into subsequent stages.

The effects of implementing the VBM concept become visible only in the long run. Property value management is not a single undertaking, but a long-term process; therefore, it requires patience from the owner and consistency in operations from the manager (UHRUSKA 2008)

The assessment of value management effectiveness requires the identification of factors affecting the value and creating measures to assess the strength and quality of these processes. Measures of effectiveness can have two forms: absolute (measurement of the value in a given period) and relative 
(measurement and relation to the value of the capital involved). Three groups of measures applied in the assessment of value management effectiveness can be distinguished: accounting, financial and market measures (JAKI 2008). Accounting measures are based on the application of various categories of the financial result. The application of profit and profit-based indicators to analyse value growth is considered not to be entirely right by many researchers, since too many factors affect the final amount of the financial result (appraisal principles, depreciation, etc.). Consequently, a second group of measures was created, namely, financial measures. The most important methods of creating and assessing value increase include cash flows, the cost and structure of capital, and a potential sustained value increase rate (SZCZEPANKOWSKI 2007). The third group includes market measures, which use both groups of measures and which make it possible to present the value in market terms. These are primarily measures of the value created and rates of return from the invested capital (JAKI 2011).

The market value of a property reflects, and is affected by, various factors that motivate human activities. These are dynamic factors, subject to constant change, of variable extent and a range of effects. On one hand, they have an impact on human activities, while on the other, they remain under the influence of those activities. The interaction of these factors shapes the value of property on the market (KUCHARSKA-STASIAK 2002).

\section{Activities aimed at increasing the value of a property}

The research includes an analysis of activities which should be undertaken on the analyzed hospital property in order to increase its market value. The aim of carrying out such an analysis is to increase the budget of the entity, while preserving the previous function of the developed part of the property hospital buildings. No liquidation of the hospital is assumed. The property is owned by the district. Its location is very good - in the centre of Brodnica and near planned new roads that would facilitate incoming and outgoing road traffic.

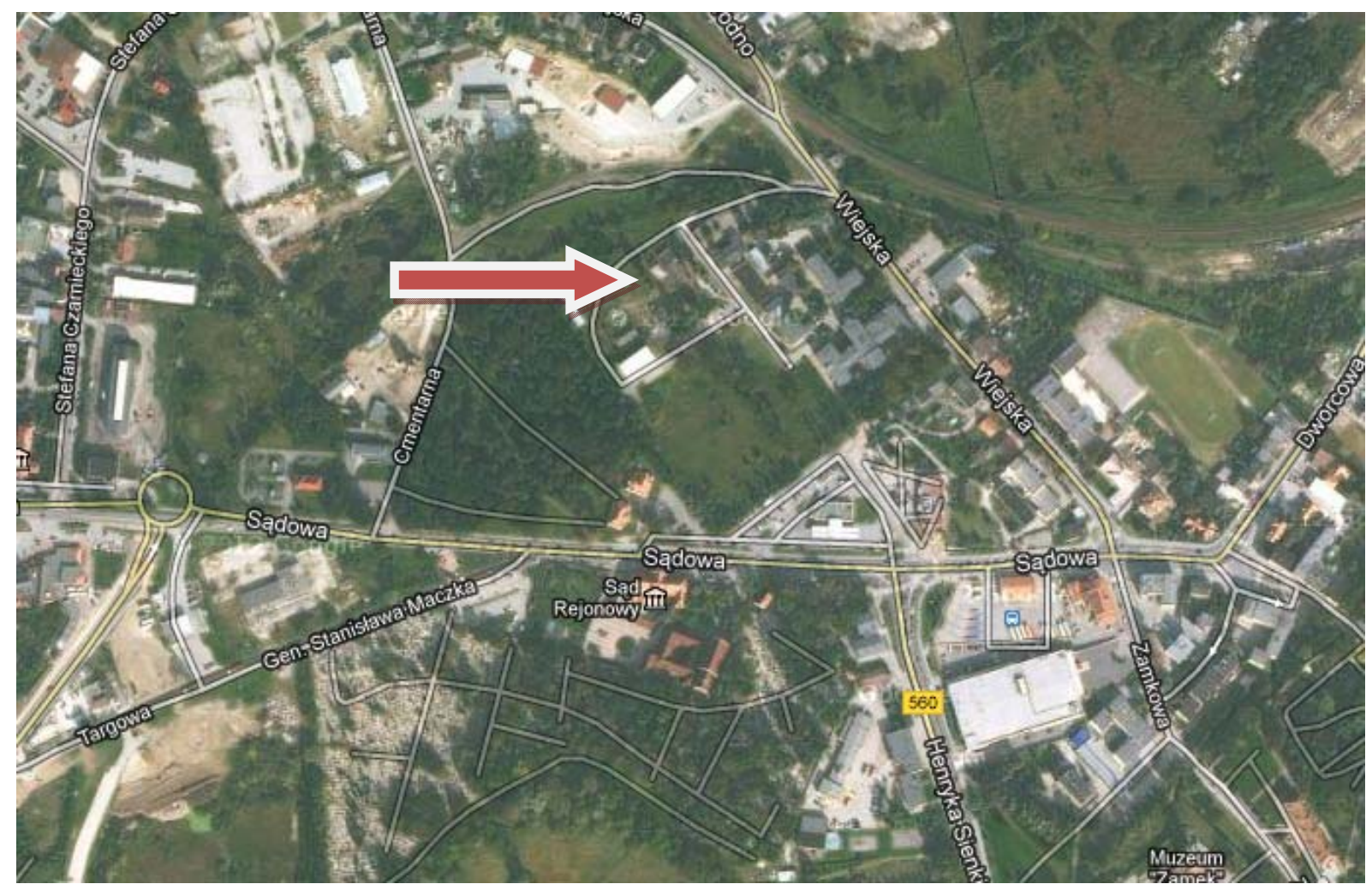

Fig. 1. Location of the examined property in the town of Brodnica. Source: own study on the basis of www.btsearch.com.

The property consists of seven developed and undeveloped plots with a total area of 3.5710 ha. The research concerned two plots with a total area of 1.5565 ha. As the examined part of the property reveals a series of barriers preventing its management, the provided scenarios are aimed at presenting 
the best property division along with the removal of existing barriers. The above mentioned barriers result from the existence of:

- utility networks -forming loops and curves in various directions, crossing the examined part of the property; this network supplies heat to the hospital and to some residential and commercial buildings in its vicinity,

- helipad for air ambulances (Photo 1) - the helipad facility is raised above the ground level and is connected with the hospital building complex by an overpass which is used for the fast transport of patients; a car park for passenger cars is located under the main field of the helipad. The developed area of the helipad is 1,044.2 $\mathrm{m}^{2}$; the building is a monolithic reinforced concrete structure, standing on reinforced concrete poles; the main barrier in the development of the property is the requirement to maintain an appropriate distance zone for the arrival and departure of helicopters and protection from the noise generated by them,

- boiler house (Photo 2) - located in the central-western part of the area; it constitutes an anthropological barrier to designing new solutions on the property,

- remains of a former coal boiler house (Photo 2) - due for demolition - provides a temporary barrier,

- warehouse buildings - three buildings in good technical condition and two buildings absolutely due for demolition.
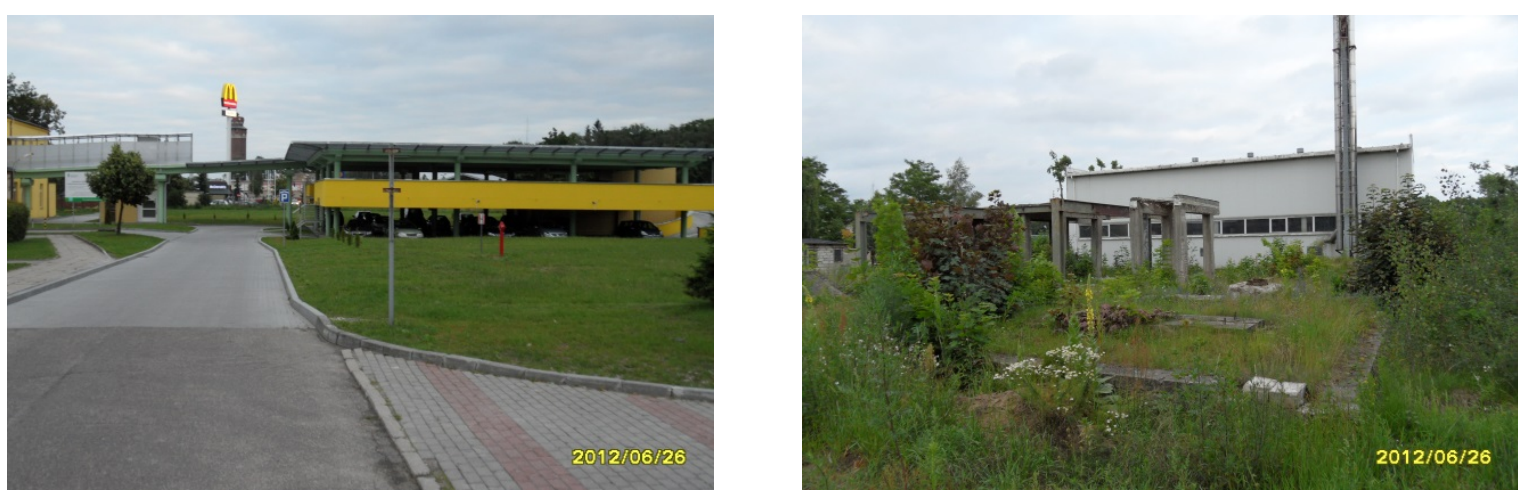

Photos 1 and 2. The view of the helipad with an overpass (on the left) and the view of the new boiler house and the remains of the old boiler house due for demolition (on the right). Source: photo by K. Kocur-Bera.

\subsection{Environmental and economic conditions of the research subject}

The examined real estate property is located in the town of Brodnica, in the Kujawsko-Pomorskie Voivodeship. According to the data provided by the Central Statistical Office, the population in 2011 reached 27,731 (www.stat.gov.pl). An automotive equipment factory, as well as food processing and clothing plants are located within its boundaries. Other industries developing in the town include the wood, furniture and paper industry. There are also factories manufacturing plastics, clothing and machines.

Brodnica occupies an area of land situated in the Drwęca river valley. The varied landscape and differentiated urban structure of the town had an unfavourable effect on the costs of the infrastructure network. Almost the entire area of the town, i.e., 2,284 ha (99.9\%) is located within the boundaries of the protected environmental area of the "Drwęca Valley", which also involves specific regulations concerning the management of those areas.

National Road No. 15 (Olsztyn)-Ostróda-Brodnica-Torun-Gniezno-Krotoszyn-Trzebnica(Wrocław) passes through Brodnica. The town also has road connections with Sierpiec (voivodehip road No. 560), Jabłonowo Pomorskie (voivodeship road No. 543 ) and Działdowo (voivodehip road No. 544). Brodnica does not have a ring road and most east-west traffic runs along national road no. 15, through the centre of the town. Since September 2010, a small ring-road, with a new bridge crossing on the Drwęca River, has connected national road no. 15 (ul. Sądowa) with voivodehip road no. 560 (ul. Podgórna). 


\subsection{Conditions concerning the specific location of the research subject}

The manner of land development of the examined property results from its basic function as a hospital. The property is situated in the central part of town, which increases the interest of investors. However, the many existing barriers of the property prevent its sale or development in the present state. Therefore, it is necessary to perform a preliminary study concerning the analysis of investment opportunities which will enable decision-making as to the further development of the examined area.

The main hospital complex is composed of buildings which are in a highly deteriorated state, both physical and functional. The element dominating the space is a modern helipad for air ambulances, connected by an overpass with the main complex of the hospital buildings.

A hardened internal road, maintained in good condition, passes centrally through the property, separating the hospital part from the utility and warehouse-storage area. In the western part of the property, the boiler house building situated in the centre constitutes a characteristic spatial element. Its location results, to a large extent, in the dysfunctionality of this area and highly limits the course of boundaries of newly-planned plots.

The property is equipped with low and high voltage power grids, water supply, and sewage and storm water drainage systems. There is no applicable local zoning plan for the examined area. According to the instructions provided in the "Study of conditions and directions of spatial development of Brodnica", the area under investigation is marked with a "UP" symbol, with intended use as areas for the development of light public services, housing and cultivated green areas, and with a "KDL" symbol, for intended use as areas for public roads of local class.

\subsection{Scenarios of possibilities concerning the division of the property with valuation of its market value}

Individual scenarios of project implementation are based on the following assumptions:

- accepting the conditions resulting from the helipad location - distance zones resulting from the Aviation Law of 2002 and the Order of the Minister of Transport and Maritime Economy of 1998 on technical and construction regulations for civil airfields;

- taking into account various management possibilities resulting from the intended use of the property (multi-family housing, light services and cultivated green areas);

- taking into account the proximity of hospital buildings, without assuming their liquidation, since this is consistent with the health care tasks assigned to the local government unit (district);

- taking into account the proximity of the municipal park and the Evangelical cemetery;

- taking into account commercial buildings intended for construction on the neighbouring plot;

- taking into account the existence of a fuel station and a McDonald's restaurant in the neighbourhood;

- taking into account the transportation link which is to be built soon, the so-called ring road of national road DK-15, Torun-Olsztyn, and the local road (Cmentarna st.);

- relocation or liquidation of technical infrastructure;

- relocation or liquidation of the boiler house;

- possibilities of demolishing warehouse facilities;

- taking into account the utilities passing through the plot;

- sectioning off a right-of-way for communication purposes of the examined property, with an area of $1,568 \mathrm{~m}^{2}$.

Five possibilities of property division were presented in the case study, distinguishing within those possibilities individual variants based on amended intended use in the study of conditions of land development in the town of Brodnica. The variants took into account the intended use for residential purposes and services as well as green areas. All assumed scenarios, together with the individual variants, are characterised by features indicating the feasibility of their implementation and comply with the applicable legal regulations. Figures no. 2, 3, 4, 5 and 6 provide graphical presentations of the individual variants of the property division scenarios. The boiler house, quite heavily limiting the use of the area, is marked on the scheme in blue. Nevertheless, the heat supplied through the network is used by some residential and service buildings. The heating capacity generated by the boiler house makes it possible to also provide heat to a broader range of recipients. In the examined scenarios, the area over the heat transfer ducts is considered as a separate plot with an area for servicing purposes in 
case of a malfunction or for network maintenance works, or as a cost related to the easement of conveyance payment.

A dark blue colour indicates a road necessary for maintaining the property and sectioned-off plots. It enables servicing and connects the area with the planned so-called small ring road. The yellow colour on the scheme indicates areas where development for the purpose of multifamily housing, services and green areas is possible. The market value of the individual scenarios was assessed according to property appraisal principles specified in the Act on Property Management of 21 August 1997 with interpretation notes.

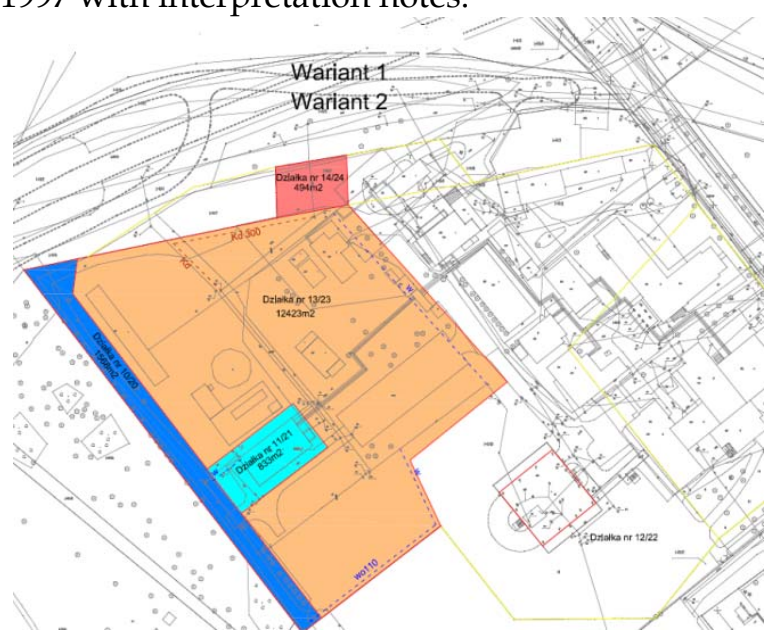

Fig. 2. Scenario 1. Source: own study

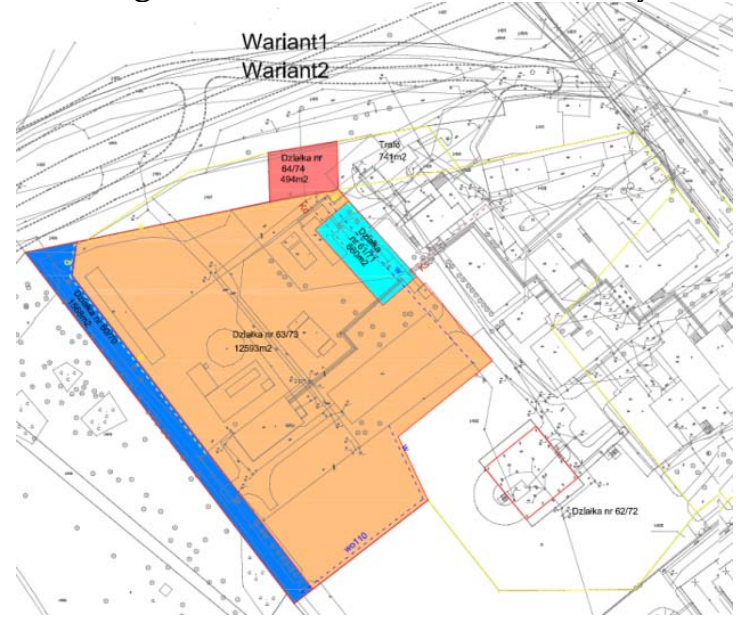

Fig. 4. Scenario 3. Source: own study

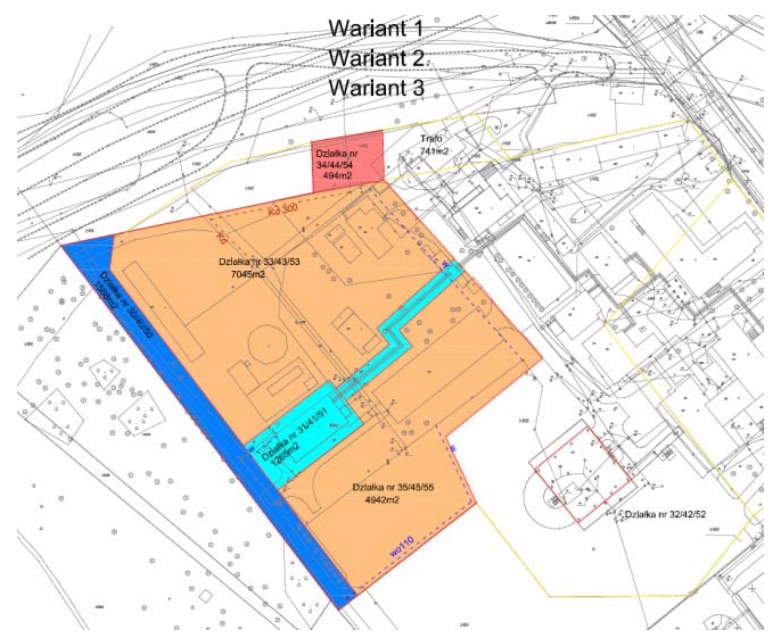

Fig. 3. Scenario 2. Source: own study

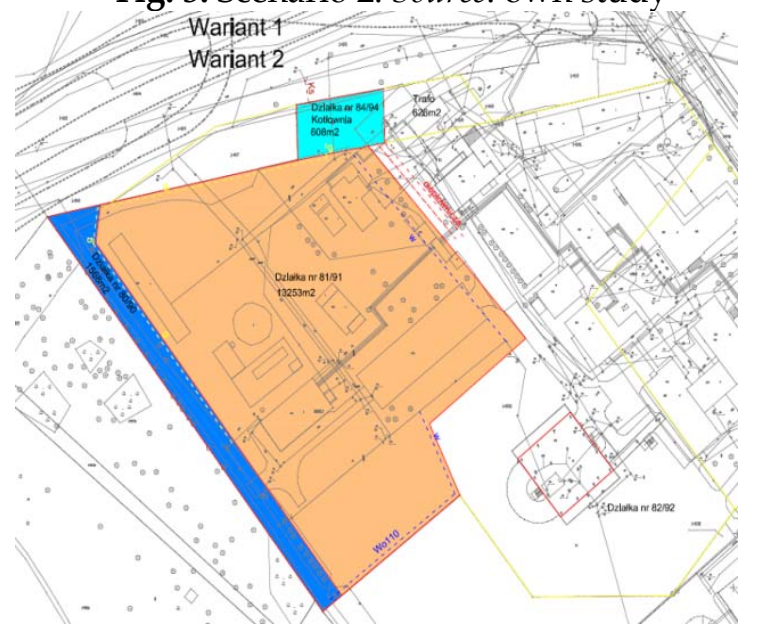

Fig. 5. Scenario 4. Source: own study

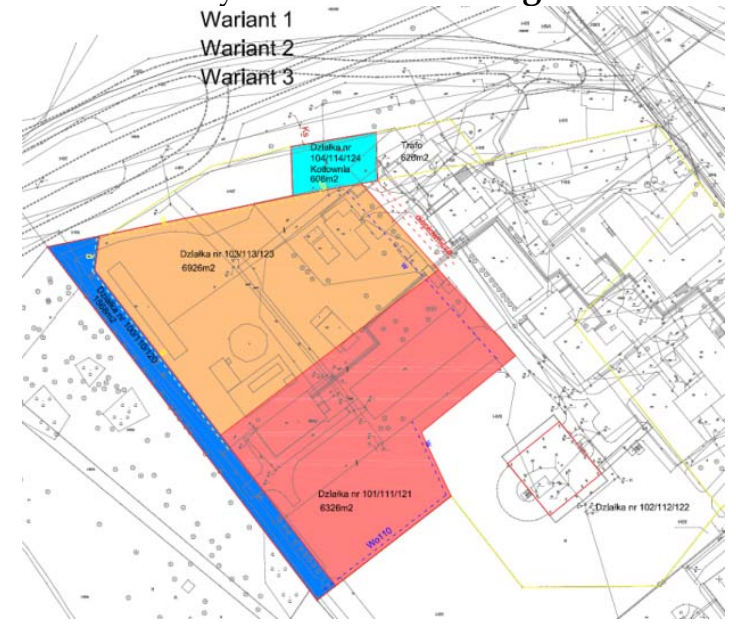

Fig. 6. Scenario 5. Source: own study 
Table 1 contains a comparison of the market value of the property, taking into account the implementation of individual scenarios together with the necessary works related to the transfer of utilities, marking out the helipad zone and establishing the transmit servitude of utilities (with a onetime payment). The market value of the property ranges from about PLN 1,800,000 to almost PLN $3,400,000$. Such a large span of property market values (almost 100\%) is caused by diversification and costs of individual works which should be performed on the property in order to bring it up to a state expected by future investors.

Table 1

The value of the property after implementation of specific scenarios

\begin{tabular}{|c|c|c|}
\hline Scenario No. & Variant No. & Value of the property [PLN] \\
\hline I & 1 & 2437100 \\
\hline & 2 & 3383200 \\
\hline II & 1 & 2166100 \\
\hline & 2 & 3041900 \\
\hline & 3 & 2682900 \\
\hline III & 1 & 1950900 \\
\hline & 2 & 2951800 \\
\hline IV & 1 & 1996000 \\
\hline & 2 & 3009600 \\
\hline V & 1 & 1818600 \\
\hline & 2 & 2845700 \\
\hline & 3 & 2480100 \\
\hline
\end{tabular}

Source: Own study.

In terms of the highest value of the property after taking into account the costs that must be borne for bringing the property up to optimum condition, the second variant in the first scenario is recommended. This variant consists of dividing the land into two investment plots for multifamily housing, taking into consideration the applicable guidelines (recommendations) set forth in the study of conditions and direction of land development established for the town of Brodnica. As part of the implementation of the variant, the following detailed work should be performed:

- sectioning off a plot for servicing the gas boiler house and complying with technical conditions,

- sectioning off plot no. 14 (or 15 for the second variant) at the transformer station, by establishing a boundary line through record plot no. 44/9 on the level of the internal road intended for servicing hospital buildings; this results from the fact that the examined property is made of record plots $44 / 9$ and $45 / 13$,

- demolishing the existing warehouse buildings in the entire area covered by the division proposal,

- establishing heating and sewage systems and a drainage and water supply system on planned plot No. 13 (23 for variant 2),

- relocating a part of the water supply system (wo110) on plot no. 13 and connecting a water supply to the boiler house,

- relocating a part of the storm water drainage system (Kd 300).

This variant would make for the highest market value of the property and considers the assumptions, barriers and criteria for optimising the division of the land. The weakest variant assumes including: an intended use for "services", the relocation of the boiler house and reconstruction of the gas, water supply and sewage systems. The differences in the individual variants result from various methods of removing the barriers existing in the examined parts of plots.

\section{Conclusion}

Value-based management of property assumes a series of activities related to property management, which are carried out in order to maximise the value of property for all stakeholders. Undertaking activities on the property can affect its market value. Certain activities in the field of property management may increase this value. In the case of developed properties, these activities can be related to the increase of income, reduction of operating expenses, improvement of the technical 
condition of the building, modernization of building fittings, regulation of the legal status of the property, renegotiation of rental conditions, promotion of the facility, selection of lessees, provision of additional auxiliary services, etc. (Uhruska, 2008). In the case of undeveloped properties, there are also some procedures which make it possible to increase their market value. In the case study carried out on a part of a hospital property, a series of procedures was performed to increase the market value of the property. In their initial phase, these activities were aimed at increasing the budget of the unit while preserving the existing functions carried out on the given part of the property (hospital function, without its liquidation). The analysis proved that the liquidation or relocation of some elements or components located on the property and sectioning off separate plots can positively affect its market value. The difference in values in the examined cases was shown to reach $100 \%$. Thus, the example of applying the property management system referred to as "value-based management" proved effective.

\section{Bibliography}

COPElAnd T., KOller T., Murrin J., 1990, Valuation: Measuring and Managing the Value of Companies, John Wiley \& Sons, New York.

JAKI A., 2008, Wycena i kształtowanie wartości przedsiębiorstwa, Wolters Kluwer, Kraków.

KUCHARSKA-STASIAK E. (red.), 2002, Wycena nieruchomości, Wydanie polskie, PFSRM, Warszawa.

Powierzchnia i ludność w przekroju terytorialnym w 2011 r., Warszawa 2011, Główny Urząd Statystyczny, WWW.stat.gov.pl, dostęp: 2013.01.08.

Rozporządzenia Ministra Transportu i Gospodarki Morskiej z dnia 31 sierpnia 1998 r. w sprawie przepisów techniczno-budowlanych dla lotnisk cywilnych (Dz. U. 1998 nr 130 poz. 859).

Studium uwarunkowań $i$ kierunków zagospodarowania przestrzennego miasta Brodnicy, Uchwała $\mathrm{Nr}$ XXVIII/307/2009 Rady Miejskiej w Brodnicy z dnia 1.12.2009 r.

RYMRZAK M., 2010, Strategie zarządzania nieruchomościami, Administrator 7-8/2010.

SZABLEWSKI A., 2011, System zarządzania wartościa przedsiębiorstwa (VBM), w. 3, dostęp: 22.03.2013 www.sgh.waw.pl/katedry/kzw/.../ZWP.\%20W.3,\%204.03.11.pdf

SZCZEPANKOWSKI P., 2007, Wycena i zarządzanie wartościa przedsiębiorstwa, Wydawnictwo Naukowe PWN, Warszawa.

UHRUSKA M., 2008, Wykorzystanie koncepcji zarządzania wartościa w sferze nieruchomości inwestycyjnych. Studia i Materiały Towarzystwa Naukowego Nieruchomości, vol. 16 nr 3.

Ustawa z dnia 3 lipca 2002 r. Prawo lotnicze, (Dz. U. 2002 Nr 130 poz. 1112 z poźn. zm.).

Ustawa z dnia 21 sierpnia 1997 r. o gospodarce nieruchomościami, (Dz. U. z 2010 nr 102 poz. 651).

WAŚNIEWSKI P., 2011, Zarzadzanie wartościa przedsiębiorstwa jako narzędzie sterowania jego działalnościa, Studia i Prace Wydziału Nauk Ekonomicznych i Zarządzania Nr 21. 